\title{
Pembinaan Kesejahteraan Keluarga (PKK) Dalam Pemberdayaan Keluarga Prasejahtera
}

\author{
Fani Novi Alvianta' ${ }^{1)}$, Agung Ary Prabowo ${ }^{2)}$, Ahmad Komarudin ${ }^{3)}$. \\ 1,2,3 Sekolah Pascasarjana, Universitas Muhammadiyah Prof.DR.HAMKA \\ fanialvianta17@gmail.com, agungaryprabowo@gmail.com, aka.komar@gmail.com
}

Article Info
Article history:
Article Accepted: June 072021
Publication : July 072021

Keywords:

Pembinaan Kesejahteraan

Keluarga, Pemberdayaan,

Keluarga Pra Sejahtera,

Administrasi Pendidikan

\begin{abstract}
Abstrak
Tujuan penelitian ini adalah mengkaji jumlah Kepala Keluarga yang sudah Sejahtera baik sisi Sosial dan Ekonomi dan menjadi bahan masukan yang bernilai bagi internal PKK. Metode penelitian yang di gunakan dalam meneliti Pembinaan Kesejahteraan Keluarga adalah Metode Kualitatif Deskriptif. Peneliti mengkaji dan melakukan penelitian dengan mendalam sehingga data yang di peroleh dapat sesuai yang diharapkan. Metode yang digunakan dalam penelitian ini adalah deskriptif kualitatif. Hasil penelitian menunjukkan bahwa $P K K$ di lingkungan RW 004 sangat aktif dalam memberdayakan kaum perempuan yang ada di lingkuan tersebut, walaupun belum semua perempuan tergerak untuk ikut berkontribusi dalam ini. Namun telah banyak aksi nyata yang diberikan oleh PKK kepada masyarakat. Namun faktanya masih banyak keluarga yang tergolong dalam keluarga pra sejahtera di lingkungan RW 004. Menurut data yang di dapat ada 350 keluarga yang tergolong dalam keluarga pra sejahtera. Hal ini dibuktikan dari data daftar keluarga yang termasuk kriteria penerima manfaat program raskin $R W 004$. Kesimpulan dalam penelitian ini adalah PKK membantu meningkatkan kesejateraan keluarga prasejahtera melalui berbagai kegiatan atau program kerja yaitu posyandu kerja, Pos Bindu, dan Jumantik. Setiap kegiatan upaya yang dilakukan telah berusahan untuk mensejahterakan keluarga pra sejahtera yang ada di wilayah tersebut. Namun masih terdapat kekurangan yang di rasakan olleh masyarakat terutama keluarga prasejahtera yang ada di wilayah tersebut. Kekurangan tersebut anatara lain kurangnya sosialisasi program kerja yang akan di laksanakan oleh PKK.
\end{abstract}

This is an open access article under the Lisensi Creative Commons AtribusiBerbagiSerupa 4.0 Internasional (c) (i) ()

\footnotetext{
Corresponding Author:

Fani Novi Alvianta

Sekolah Pascasarjana, Universitas

Muhammadiyah Prof.DR.HAMKA

fanialvianta17@gmail.com
}

\section{PENDAHULUAN}

Pembinaan Kesejahteraan Keluarga (PKK) adalah sebuah organisasi kemasyarakatan desa yang menggerakkan partisipasi masyarakat desa dalam pembangunan, juga dalam kegiatan pertumbuhan desa. (Rantung, Mandey, \& Londa, 2014). Sedangkan Arisandi menyatakan bahwa PKK adalah organisasi masyarakat yang diperuntukkan bagi wanita agar dapat mengembangkan dirinya didalam masyarakat.(Arisandi, 2015)

Gerakan PKK (Pembinaan Kesejahteraan Keluarga) memiliki tujuan untuk memberdayakan keluarga sejahtera dengan tidak membeda-bedakan golongan, agama, partai dan lain-lain. Hal ini menarik perhatian Pemerintah yang selanjutnya Gerakan PKK diatur dan dibina oleh Departemen Dalam Negeri. Berdasarkan Keputusan Presiden No. 28 Tahun 1980, tentang Perubahan Lembaga Sosial Desa (LSD) menjadi Lembaga Ketahanan Masyarakat Desa (LKMD) dan PKK sebagai Seksi ke 10 di LKMD. Berdasarkan Keputusan Menteri Dalam Negeri No. 4 
Tahun 1982, Tim Penggerak PKK Pusat dibentuk dan dipimpin oleh Ibu Amir Mahmud, isteri Menteri Dalam Negeri pada tahun 1982.

Djohani menyatakan, pemberdayaan adalah suatu proses untuk memberikan kekuasaan (power) kepada pihak yang lemah (powerless) dan mengurangi kekuasaan (disempowered) kepada pihak yang terlalu berkuasa (powerful) sehingga terjadi keseimbangan. Begitu pula menurut Rappaport, pemberdayaan yaitu suatu cara dengan mana rakyat, dan komunitas diarahkan untuk mampu menguasai dan berkuasa atas kehidupannya (Anwas, 2013)

Memberdayakan masyarakat berarti mengupayakan peningkatan harkat dan martabat lapisan masyarakat yang dalam kondisi sekarang tidak mampu untuk melepaskan diri dari perangkap kemiskinan dan keterbelakangan. Pemberdayaan yaitu upaya untuk membangun daya/kekuasaan itu, dengan mendorong, memotivasi, dan membangkitkan kesadaran akan potensi yang dimilikinya serta berupaya mengembangkannya .

Agen pemberdayaan menurut Chamber petugas non formal adalah individu yang memiliki dedikasi secara sukarela untuk membantu memberdayakan masyarakat baik yang dikelola oleh suatu lembaga LSM atau secara pribadi. Petugas non formal tersebut yaitu: relawan, pekerja sosial, kader PKK, kader Posdaya, mahasiswa, ulama, simpatisan, dan yang lainnya. Tugas pelaku pemberdayaan ialah mendorong dan menciptakan individu serta masyarakat agar mampu melakukan perubahan perilaku menuju ke arah kemandirian (berdaya). (Pranarka \& Moeljarto, 1996)

PKK sebagai agen pemberdayaan merupakan wadah untuk memberdayakan keluarga pra sejahtera yang ada di lingkuannya. Keluarga adalah unit terkecil masyarakat yang terdiri dari suami-istri atau suami-istri dan anaknya atau ayah dan anaknya atau ibu dan anaknya. Secara implisit dalam batasan ini yang dimaksud dengan anak adalah anak yang belum menikah. Apabila, ada anak yang sudah menikah dan tinggal bersama suami/istri atau anak-anaknya, maka yang bersangkutan adalah keluarga tersendiri (keluarga lain atau keluarga baru).

Sunarti mengatakan bahwa keluarga pra sejahtera adalah keluarga yang belum mampu memenuhi kebutuhan dasarnya (basic needs) secara minimal, contohnya kebutuhan akan pangan,sandang, papan, kesehatan, dan pendidikan (Sunarti, 2011).

Penelitian tentang PKK telah banyak dilakukan sesbelumnya. Dalam penelitian Organisasi Pemberdayaan dan Kesejahteraan Keluarga sebagai Sarana Pemberdayaan Perempuan menghasilkan sebuah penelitian yaitu organisasi PKK dapat menjadi wadah atau sarana pemberdayaan perempuan, terutama bagi anggotanya. Meskipun demikian, organisasi PKK belum dapat menumbuhkan kemitrasejajaran dengan laki-laki karena program-programnya masih berorientasi kepada peningkatan kesejahteraan keluarga, dan anggotanya mayoritas perempuan yang tidak bekerja atau pensiunan (Aslichati, 2011).

Kemudian dalam penelitian Pelaksanaan Peran Tim Penggerak PKK dalam Memberdayakan Perempuan menghasilkan sebuah penelitian yaitu dengan adanya pemberdayaan dari PKK dapat meningkatkanperan perempuan dalam pembangunan untuk menuju tujuan Pembangunan Milenium yang harus dicapai tahun 2015 antara lain adalah kesetaraan gender/Pengarusutamaan Gender dan pemberdayaan perempuan (Riana, Sjamsuddin, \& Hayat, 2014).

Penelitian ini memiliki tujuan yang berbeda dari kelima penelitian terdahulu yang telah dijabarkan tersebut. Penelitian ini bertujuan untuk memberdayakan keluarga pra sejahtera yang ada di lingkungan tersebut melalui organisasi PKK. Dengan dilakukan penelitian ini juga kami bertujuan untuk melihat sejauh mana peran aktif PKK dalam memberdayakan keluarga pra sejahtera agar dapat memiliki kreativitas yang dapat menunjang perekonomian mereka, agar keluarga tersebut menjadi lebih sejahtera?

Penelitian ini diharapkan dapat memberikan kontribusi positif bagi internal PKK khususnya diwilayah yang kami teliti untuk memaksimalkan eksistensinya sesuai karakteristik masyarakat sekitar, serta dapat mengembangkan pengetahuan dan wawasan ilmiah, serta sebagai tambahan referensi di bidang pendidikan. 
Penelitian ini juga bermaksud menyadarkan masyarakat untuk berpartisipasi aktif maupun pasif dalam setiap kegiatan yang dilakukan PKK. Partisipasi diartikan dengan keikutsertaan seseorang dalam suatu kegiatan dalam masyarakat. Hal ini sesuai dengan pendapat Damsar (2012) secara etimologis konsep dari partisipasi dapat ditelusuri akar katanya berasal dari bahasa inggris, yaitu kata "Part" yang berarti bagian. Jika kata "Part" dikembangkan menjadi kata kerja, maka kata ini menjadi "to Participate" yang bermakna turut ambil bagian.

\section{METODE PENELITIAN}

Pendekatan dalam penelitian ini menggunakan deskriptif kualitatif. Menurut Lambert \& Lambert The least "theoretical" qualitative descriptive studies of all qualitative approaches to study are. Therefore, qualitative descriptive studies are the least burdened by a pre-existing theoretical or conceptual commitment compared with other qualitative methods (Lambert \& Lambert, 2012).

Tujuan dari penelitian deskriptif kualitatif adalah untuk menggambarkan suatu kejadian atau fenomena dan segala karakteristiknya. Hal ini sama seperti yang disampaikan oleh Gall bahwa, Descriptive work has as its aim to identify a phenomenon and its characteristics. This work is concerned primarily about what has happened, rather than how or why. Observation and survey methods therefore also help to collect data (Gall, Gall, \& Borg, 2007).

Lebih lanjut Lambert menyampaikan, Qualitative descriptive research data collection focuses on exploring the essence of the particular events under study. Therefore, the collection of data includes interviews with minimum to moderate, organized, open-ended, person or focus group. Data collection can, however, also involve observations and analysis of records, papers, photographs and documents (Lambert \& Lambert, 2012)

Dalam penelitian ini menggunakan sumber primer dan sumber sekunder untuk mendapatkan hasil dari peneltian ini. Menurut Sugiyono sumber primer adalah data yang langsung didapat oleh peneliti, sedangkan sumber sekunder adalah data yang didapat secara tidak langsung oleh peneliti misalnya dokumen (Sugiyono, 2010). Selain itu juga penelitian ini menggunakan sampling purposive yaitu meneliti dengan menyebarkan kuesioner kepada kelurga pra sejahtera (Sugiyono, 2012)

Penelitian ini menggunakan beberapa teknik pengumpulan data, yaitu kuesiner (angket), observasi, wawancara, dan dokumentasi (Arikunto, 2008). Kuesioner atau angket dalam penelitian ini adalah angket semi terbuka a,b,c,d dimana pertanyaan terdiri dengan jawaban yang sudah tersusun rapi tetapi masih dapat kemungkinan untuk tambahan jawaban yang lainnya (Sungarimbun \& Efendi, 2008).

Indikator yang digunaka dalam penyusunan kuesioner dalam penelitian ini adalah sebagai berikut:

a. Identitas responden

b. Pengetahuan responden tentang PKK

c. Keterlibatan responden dalam kegiatan PKK

d. Dampak PKK terhadap responden

e. Pengetahuan responden tentang bantuan yangberasal dari Pemerintah

f. Tanggapan responden tentang kinerja PKK

Teknik analsis data dari hasil jawaban responden menggunakan analisa statistik deskriptif yaitu jawaban dari responden atau data disajian dalam bentuk tabel prosentase. Untuk memperoleh prosentase (frekuensi relatif) digunaan rumus sebagai berikut: (Sudijono, 2010)

Keterangan :

$$
P=\frac{F}{N} x 100 \%
$$

$\mathrm{P}=$ Angka Persentase

$\mathrm{F}=$ Frekuensi yang sedang dicari persentasenya

$\mathrm{N}=$ Number of Cases (Jumlah Frekuensi/ Banyanya Individu) 


\section{HASIL DAN PEMBAHASAN \\ 3.1.Hasil Penelitian}

Masyarakat yang berada di wilayah kerja PKK RW 004 berjumlah 3.783 Kepala Keluarga. Dari jumlah kepala keluarga tersebut, terdapat kurang lebih 350 keluarga yang tergolong dalam keluarga pra sejahtera.

Tabel 1 Jumlah Keluarga Pra Sejahtera di Wilayah RW 004 Rawa Buaya, Kecamatan Cengkareng, Jakarta Barat

\begin{tabular}{cc}
\hline Tahun & Jumlah Keluarga Pra Sejahtera \\
\hline $2012-2017$ & 600 \\
\hline $2017-2022$ & 350 \\
\hline
\end{tabular}

Sumber: Data administratif PKK RW 004

Berdasarkan tabel di atas, dapat diketahui bahwa jumlah keluarga yang tergolong keluarga pra sejahtera di wilayah RW 004 mengalami penurunan dari yang berjumlah 600 keluarga menjadi 350 keluarga. Namun penurunan ini disebabkan oleh kematian dan pindahnya warga tersebut ke daerah lain.

\subsubsection{Latar Belakang Keluarga Pra Sejahtera di Wilayah RW 004 Rawa Buaya}

Pendidikan adalah salah satu faktor yang berpengaruh terutama dalam rangka persiapan menuju dunia kerja, selain itu tingkat pendidikan juga sangat mempengaruhi pola pikir suatu masyarakat. Untuk mengetahui komposisi responden menurut tingkat pendidikan dapat dilihat pada tabel berikut ini :

Tabel 2 Proporsi Penduduk Keluarga Pra Sejahtera Menurut Tingkat Pendidikan

\begin{tabular}{cccc}
\hline No & Tingkat Pendidikan & Frekuensi & Prosentase \\
\hline 1 & Tidak tamat SD & 3 & $9 \%$ \\
\hline 2 & SD & 9 & $26 \%$ \\
\hline 3 & SMP & 15 & $43 \%$ \\
\hline 4 & SMA & 6 & $17 \%$ \\
\hline 5 & Perguruan Tinggi & 2 & $5 \%$ \\
\hline & Jumlah & $\mathbf{3 5}$ & $\mathbf{1 0 0 \%}$ \\
\hline
\end{tabular}

Sumber: Data olahan observasi peneliti 2017

Berdasarkan tabel 2, proporsi jumlah penduduk keluarga pra sejahtera berdasarkan tingkat pendidikan yang telah ditempuh, terlihat bahwa konsentrasi terbesar penduduk adalah tamat SMP sebanyak 15 responden dengan prosentase sebesar 43\%, kemudian SD sebanyak 9 responden dengan prosentase sebesar $26 \%$, lalu SMA sebanyak 6 responden dengan prosentase sebesar 17\%, tidak tamat SD sebanyak 3 responden dengan prosentase sebesar $9 \%$ dan sisanya sampai tingkat perguruan tinggi sebanyak 2 responden dengan prosentase sebesar 5\%.

Tabel 3 Proporsi Keluarga Pra Sejahtera Menurut Mata Pencaharian

\begin{tabular}{clcc}
\hline No & \multicolumn{1}{c}{ Jenis Pekerjaan } & Frekuensi & Prosentase \\
\hline 1 & Ibu Rumah Tangga & 15 & $43 \%$ \\
\hline 2 & Pembantu Rumah Tangga & 11 & $31 \%$ \\
\hline 3 & Buruh & 6 & $17 \%$ \\
\hline 4 & Wiraswasta & 3 & $9 \%$ \\
\hline & Jumlah & 35 & $100 \%$ \\
\hline
\end{tabular}

Sumber : Olahan Data Primer, 2017

Berdasarkan tabel 3 di atas jumlah responden sebanyak 35 orang diperoleh jawaban terbanyak tentang jenis pekerjaan responden dan data yang diperoleh ialah sebanyak 15 responden atau sekitar $43 \%$ yang menjawab memiliki profesi sebagai Ibu Rumah Tangga (IRT), kemudian sebanyak 11 responden atau sekitar 31\% menjawab bahwa mereka berprofesi sebagai pembantu rumah tangga yaitu biasanya mereka 
mencuci dan menyetrika pakaian di rumah tetangga yang lebih mampu. Sebanyak 6 responden atau sekitar 17\% menjawab bekerja sebagai buruh di pabrik atau konveksi yang ada di sekitar lingkungan tempat tinggal mereka, dan sisanya sebanyak 3 responden atau sekitar 9\% menjawab berprofesi sebagai wiraswasta. Maka dapat ditarik eksimpulan bahwa sebagian besar pekerjaan Ibu-ibu tersebut hanya sebagai Ibu Rumah Tangga (IRT).

Tabel 4 Jawaban Responden Tentang Penghasilan Perbulan yang Diperoleh

No Jumlah Penghasilan yang diperoleh Frekuensi Prosenta

\begin{tabular}{cccc}
\hline 1 & Kurang dari Rp 1.000.000,00 & 30 & $86 \%$ \\
\hline 2 & Kurang dari RP 5.000.000,00 & 4 & $11 \%$ \\
\hline 3 & Kurang dari Rp 10.000.000,00 & 1 & $3 \%$ \\
\hline & Jumlah & 35 & $100 \%$ \\
\hline
\end{tabular}

Sumber : Olahan Data Primer, 2017

Berdasarkan tabel 4 tersebut jawaban dari 35 responden tentang penghasilan perbulan yang diperoleh mereka adalah sebanyak 30 responden dengan prosentase sebesar $86 \%$ berpengahsilan kurang dari RP 1.000.000,00, kemudian terdapat 4 responden memiliki prosentase sebesar $11 \%$ yang memiliki penghasilan kurang dari RP 5.000.000,00 dan sisanya sebanyak 1 responden memiliki prosentase sebesar 3\% menjawab berpenghasilan kurang dari Rp 10.000.000,00 bagi mereka yang berprofesi sebagai wiraswasta dan dapat mencukupi kebutuhan sehari-harinya.

Tabel 5 Jumlah Tangungan dalam Keluarga Responden

\begin{tabular}{cccc}
\hline No & Jumlah Tanggungan & $\begin{array}{c}\text { Frekuen } \\
\text { si }\end{array}$ & $\begin{array}{c}\text { Prosenta } \\
\text { se }\end{array}$ \\
\hline 1 & 2 & 4 & $11 \%$ \\
\hline 2 & 3 & 4 & $11 \%$ \\
\hline 3 & 4 & 7 & $20 \%$ \\
\hline 4 & 5 & 12 & $35 \%$ \\
\hline 5 & Lain-lain & 8 & $23 \%$ \\
\hline & Jumlah & $\mathbf{3 5}$ & $\mathbf{1 0 0 \%}$ \\
\hline
\end{tabular}

Sumber : Olahan Data Primer, 2017

Berdasarkan tabel 5 di atas, dapat diperoleh keterangan tentang jumlah tanggungan dalam keluarga responden terdapat 12 responden dengan prosentase sebesar 35\% menjawab memiliki tanggungan sebanyak 5 orang, sebanyak 8 responden dengan prosentase sebesar $23 \%$ menjawab lain-lain, sebanyak 7 responden dengan prosentase sebesar $20 \%$, sebanyak 4 responden dengan prosentase sebesar $11 \%$ menjawab memiliki tanggungan sebanyak 2 orang dan sisanya dengan proporsi sama menjawab memiliki tanggungan sebanyak 2 orang. Dari tabel di atas dapat ditarik kesimpulan bahwa tanggungan yang dimiliki keluarga paling banyak berjumlah 5 orang sedangkan jumlah penghasilan perbulan rata-rata kurang dari satu juta rupiah sehingga berdampak pada pemenuhan kebutuhan yang tidak tercukupi.

Tabel 6 Keterangan Tentang Kecukupan Penghasilan yang diperoleh Responden

\begin{tabular}{ccccc}
\hline No & Pertanyaan & Jawaban & Frekuensi & Prosentase \\
\hline 1 & $\begin{array}{l}\text { Apakah penghasilan Anda cukup } \\
\text { dalam memnuhi kebutuhan sehari- } \\
\text { hari keluarga Anda? }\end{array}$ & Ya & 20 & $57 \%$ \\
& & & & \\
\cline { 2 - 4 } & Jumlah & Tidak & 15 & $43 \%$ \\
\hline
\end{tabular}

Sumber : Olahan Data Primer, 2017 
Berdasarkan hasil penelitian pada tabel 6 di atas, dapat diperoleh keterangan mengenai kecukupan penghasilan yang diperoleh responden. Dari jumlah responden sebanyak 35 orang, menghasilkan 20 responden memiliki prosentase sebesar 57\% menjawab penghasilan yang mereka dapatkan dalam satu bulan dapat mencukupi kebutuhan sehari-hari mereka dan sisanya sebanyak 15 responden dengan prosentase sebesar $43 \%$ menjawab penghasilan yang mereka dapatkan tersebut tidak cukup dalam memenuhi kebutuhan sehari-hari mereka.

\subsubsection{Pengetahuan dan Keterlibatan Responden tentang PKK}

Tabel 7 Keterangan Tentang Pengetahuan Responden Mengenai Keberadaan PKK di Lingkungannya

\begin{tabular}{ccccc}
\hline No & Pertanyaan & Jawaban & Frekuensi & Persentase \\
\hline 1 & $\begin{array}{l}\text { Apakah Anda mengetahui tentang } \\
\text { PKK yang ada di lingkungan tempat }\end{array}$ & Ya & 10 & $28 \%$ \\
\cline { 2 - 4 } & & Tidak & 25 & $72 \%$ \\
\hline \multicolumn{2}{c}{ tinggal Anda? } & & 35 & $100 \%$ \\
\hline
\end{tabular}

Sumber : Olahan Data Primer, 2017

Berdasarkan hasil penelitian tabel 7 di atas, dapat diperoleh keterangan mengenai pengetahuan responden mengenai keberadaan PKK di lingkungan tempat tinggal mereka. Dari jumlah responden sebanyak 35 orang, menghasilkan 25 responden memiliki prosentase sebesar $72 \%$ menjawab bahwa mereka tidak mngetahui tentang PKK yang ada di lingkungan tempat tinggal mereka, dan sisanya sebanyak 10 responden dengan prosentase sebesar $28 \%$ menjawab bahwa mereka mengetahui tentang PKK yang ada di lingkungan mereka dari pembicaraan dengan tetangga sekitar.

Tabel 8 Keterangan Tentang Keaktifan PKK di Lingkungan Rumah Responden

\begin{tabular}{ccccc}
\hline No & Pertanyaan & Jawaban & Frekuensi & Persentase \\
\hline 1 & $\begin{array}{l}\text { Apakah PKK di lingkungan } \\
\text { rumah Anda berjalan aktif ? }\end{array}$ & Ya & 13 & $37 \%$ \\
& & &
\end{tabular}

\begin{tabular}{cccc}
\cline { 2 - 3 } & Tidak & 22 & $63 \%$ \\
\hline Jumlah & 35 & $100 \%$ \\
\hline
\end{tabular}

Sumber : Olahan Data Primer, 2017

Berdasarkan hasil penelitian pada tabel 8 di atas, dapat diperoleh keterangan tentang keaktifan PKK di lingkungan rumah responden. Dari jumlah responden sebanyak 35 orang, terdapat 22 responden dengan prosentase $63 \%$ menjawab "tidak" dan sisanya sebanyak 13 responden dengan prosentase sebanyak $37 \%$ menjawab "ya".

Dari hasil observasi peneliti, untuk responden yang menjawab "ya" rata-rata mereka memiliki balita dan lansia sehingga mereka ikut serta dalam kegiataan Posyandu dan Poslindu yang diadakan oleh PKK. Sedangkan responden yang menjawab "tidak" mereka tidak memiliki balita maupun lansia serta memiliki kesibukan di luar rumah

Tabel 9 Keterangan Tentang Program Kerja PKK yang diketahui oleh Responden

\begin{tabular}{ccccc}
\hline No & Pertanyaan & Jawaban & Frekuensi & Persentase \\
\hline \multirow{2}{*}{$\begin{array}{l}\text { Ada berapakah program kerja PKK yang } \\
\text { Anda ketahui }\end{array}$} & 1 & 7 & $20 \%$ \\
\cline { 2 - 4 } & & 2 & 6 & $17 \%$ \\
\cline { 2 - 4 } & & 3 & 10 & $29 \%$ \\
\hline & Lain-lain & 12 & $34 \%$ \\
\hline
\end{tabular}

Sumber : Olahan Data Primer, 2017 
Dari hasil penelitian pada tabel 4.9 di atas, dapat diperoleh keterangan tentang program kerja PKK yang diketahui oleh rsesponden. Dari 35 responden, terdapat 7 responden dengan prosentase 30\% menjawab 1 program kegiatan, lalu sebanyak 6 responden dengan prosentase sebesar $17 \%$ menjawab 2 program, kemudian 10 responden dengan prosentase sebesar $29 \%$ menjawab 3 program kerja, dan sisanya sebanyak 12 responden dengan prosentase sebesar 34\% menjawab lain-lain yaitu lebih dari 3 program. Bagi mereka yang menjawab "lain-lain" atau lebih dari 3 program kerja karena mereka mengikuti kegiatan pengajian bulanan yang diadakan oleh PKK.

Tabel 10 Keterangan Tentang Jadwal Rutin Program Posyandu yang dilakukan oleh PKK

\begin{tabular}{ccccc}
\hline No & Pertanyaan & Jawaban & Frekuensi & Persentase \\
\hline 1 & $\begin{array}{l}\text { Apakah kegiatan Posyandu yang } \\
\text { dilakukan oleh PKK berjalan } \\
\text { sesuai dengan jadwalnya ? }\end{array}$ & Ya & 10 & $29 \%$ \\
\cline { 3 - 5 } & & & \\
\cline { 2 - 4 } & Tumlah & Tidak & 20 & $57 \%$ \\
\hline
\end{tabular}

Sumber : Olahan Data Primer, 2017

Dari hasil penelitian pada tabel $10 \mathrm{di}$ atas, dapat diperoleh keterangan tentang jadwal rutin program Posyandu yang dilakukan oleh PKK. Dari 35 responden, terdapat 20 responden dengan prosentase sebesar 57\% menjawab "tidak" bahwa kegiatan Posyandu berjalan tidak sesuai dengan jadwal yang ada, kemudia sebanyak 10 responden dengan prosentase sebesar 29\% menajwab "ya" bahwa kegiatan Posyandu berjalan sesuai dengan jadwal yang ada, dan sisanya sebanyak 5 responden dengan prosentase sebesar 14\% tidak menjawab. Bagi mereka yang menjawab "tidak" karena PKK kurang mensosialisasikan mengenai jadwal pasti pelaksanaan kegiatan Posyandu sehingga banyak dari responden yang tidak mengetahuinnya.

Tabel 11 Keterangan Tentang Dampak Kegiatan Posyandu bagi Kesehatan Anak Responden

\begin{tabular}{ccccc}
\hline No & \multicolumn{1}{c}{ Pertanyaan } & Jawaban & Frekuensi & Persentase \\
\hline 1 & $\begin{array}{l}\text { Apakah Anda merasa terbantu dalam } \\
\text { kesehatan anak Anda dengan kegiatan } \\
\text { Posyandu tersebut? }\end{array}$ & Ya & 35 & $100 \%$ \\
& & & \\
& & &
\end{tabular}

\begin{tabular}{lccc}
\cline { 2 - 3 } & Tidak & 0 & $0 \%$ \\
\hline Jumlah & 35 & $100 \%$ \\
\hline
\end{tabular}

Sumber : Olahan Data Primer, 2017

Dari hasil penelitian pada tabel $11 \mathrm{di}$ atas, dapat diperoleh keterangan tentang dampak kegiatan Posyandu bagi kesehatan anak responden. Dari 35 responden yang ada, seluruhnya menjawab "ya" dengan prosentase sebesar 100\% karena dengan adanya kegiatan Posyandu kesehatan balita yang responden miliki menjadi lebih terkontrol. Selain itu biaya yang dikeluarkan juga sesuai dengan kemampuan yang responden miliki. Oleh sebab itu mereka tidak merasa terbebani dan selalu ikut serta dalam kegiatan Posyandu tersebut.

Tabel 12 Keterangan Tentang Jadwal Rutin Kegiatan Pos Bindu yang dilaksanakan oleh PKK

\begin{tabular}{clccc}
\hline No & \multicolumn{1}{c}{ Pertanyaan } & Jawaban & Frekuensi & Persentase \\
\hline 1 & $\begin{array}{l}\text { Apakah kegiatan Poslindu yang } \\
\text { dilakukan oleh PKK berjalan }\end{array}$ & Ya & 12 & $34 \%$ \\
& sesuai dengan jadwalnya?
\end{tabular}




$\begin{array}{cccc} & \text { Tidak menjawab } & 3 & 9 \% \\ \text { Jumlah } & & 35 & 100 \%\end{array}$

Sumber : Olahan Data Primer, 2017

Berdasarkan hasil penelitian pada tabel 12 di atas, dapat diperoleh keterangan tentang jadwal rutin program Poslindu yang dilakukan oleh PKK. Dari 35 responden, terdapat 20 responden memiliki prosentase sebesar $57 \%$ menjawab "tidak" kemudian terdapat 12 responden memiliki prosentase sebesar 34\% menjawab "ya" dan sisanya sebanyak 3 responden prosentase memiliki sebesar 9\% tidak menjawab. Bagi responden yang menjawab "tidak" karena PKK kurang mensosialisasikan pastinya tanggal dalam pelaksanaan kegiatan Poslindu, sehingga banyak masyarakat yang tidak mengetahui kegiatan tersebut.

Tabel 13 Keterangan Tentang Dampak Kegiatan Poslindu terhadap Kesehatan Lansia

\begin{tabular}{|c|c|c|c|c|}
\hline No & Pertanyaan & Jawaban & Frekuensi & Prosentase \\
\hline \multirow[t]{3}{*}{1} & \multirow{3}{*}{$\begin{array}{l}\text { Apakah Anda merasa terbantu dalam } \\
\text { kesehatan lansia yang ada dalam } \\
\text { keluarga Anda dengan kegiatan Poslindu } \\
\text { tersebut? }\end{array}$} & $\mathrm{Ya}$ & 21 & $60 \%$ \\
\hline & & Tidak & 7 & $20 \%$ \\
\hline & & Tidak menjawab & 7 & $20 \%$ \\
\hline & Jumlah & & 35 & $100 \%$ \\
\hline
\end{tabular}

Sumber : Olahan Data Primer, 2017

Berdasarkan tabel 13 di atas, dapat diperoleh keterangan tentang dampak kegiatan Poslindu terhadap kesehatan lansia. Dari 35 responden, terdapat sebanyak 21 responden dengan prosentase sebesar 60\% menjawab "ya" karena dengan adanya kegiatan Poslindu kesehatan lansia yang ada di lingkungan RW 004 menjadi lebih terkontrol. Kemudian sebanyak 7 responden dengan prosentase sebesar $20 \%$ menjawab "tidak" karena dalam keluarga mereka tidak terdapat lansia, dan sisanya sebanyak 7 responden dengan prosentase sebesar $20 \%$ tidak memberikan jawabannya.

Tabel 14 Keterangan Tentang Jadwal Rutin Program Jumantik yang dilakukan PKK

\begin{tabular}{ccccc}
\hline No & \multicolumn{1}{c}{ Pertanyaan } & Jawaban & Frekuensi & Prosentase \\
\hline 1 & $\begin{array}{l}\text { Apakah kegiatan Jumantik (Juru } \\
\text { Pemantau Jentik) yang dilakukan } \\
\text { oleh PKK berjalan sesuai dengan } \\
\text { jadwalnya? }\end{array}$ & Ya & 28 & $80 \%$ \\
\cline { 2 - 4 } & Jumlah & Tidak & 7 & $20 \%$ \\
\hline
\end{tabular}

Sumber : Olahan Data Primer, 2017

Berdasarkan hasil penelitian pada tabel 14 di atas, dapat diperoleh keterangan mengenai jadwal rutin program Jumantik yang dilakukan oleh PKK. Responden sebanyak 35 orang, menghasilkan 28 responden memiliki prosentase sebesar $80 \%$ menjawab "ya" dan sisanya sebanyak 7 responden dengan prosentase sebesar $20 \%$ menjawab "tidak". Bagi responden yang menjawab "ya" karena mereka sedang berada di rumahsaat pemantau jentik dilaksanakan dan responden mengikuti anjuran yang diberikan oleh Jumantik (Juru Pemantau Jentik) dalam mengurangi dampak penyakit DBD. Sedangkan responden yang menjawab "tidak" mereka memiliki kesibukan di luar rumah sehingga tidak berpartisipasi dalam kegiatan tersebut. 
Tabel 15 Keterangan Tentang Dampak Kegiatan Jumantik terhadap Kebersihan Tempat Tinggal

\begin{tabular}{clccc}
\multicolumn{5}{c}{ Responden } \\
\hline No & \multicolumn{1}{c}{ Pertanyaan } & Jawaban & Frekuensi & Prosentase \\
\hline $\mathbf{1}$ & $\begin{array}{l}\text { Apakah Anda merasa } \\
\text { terbantu dalam menjaga } \\
\text { kebersihan tempat tinggal }\end{array}$ & Ya & 26 & $74 \%$ \\
& $\begin{array}{l}\text { Anda dnegan kegiatan } \\
\text { Jumantik tersebut? }\end{array}$ & Tidak & 9 & \\
\hline & Jumlah & & 35 & $100 \%$
\end{tabular}

Sumber : Olahan Data Primer, 2017

Berdasarkan hasil penelitian pada tabel 15 di atas, dapat diperoleh keterangan mengenai dampak kegiatan Jumantik terhadap kebersihan tempat tinggal responden. Dari jumlah 35 responden, terdapat 26 responden dengan prosentase sebesar $74 \%$ menjawab "ya" bahwa program Jumantik ini membantu dalam menjaga kebersihan lingkungan tempat tinggal responden dan sisanya sebanyk 9 responden dengan prosentase sebesar $26 \%$ menjawab "tidak" karena responden menjawab petugas Jumantik tidak melakukan pengontrol secara menyeluruh ke rumah-rumah warganya.

Tabel 16 Keterangan Tentang Keterlibatan Responden terhadap 3 Program PKK (Posyandu, Poslindu dan Jumantik)

\begin{tabular}{ccccc}
\hline No & \multicolumn{1}{c}{ Pertanyaan } & Jawaban & Frekuensi & Prosentase \\
\hline 1 & $\begin{array}{l}\text { Apakah Anda terlibat dalam ketiga } \\
\text { program PKK tersbut (Posyandu, }\end{array}$ & Ya & 10 & $29 \%$ \\
& Poslindu dan Jumantik) ? & & &
\end{tabular}

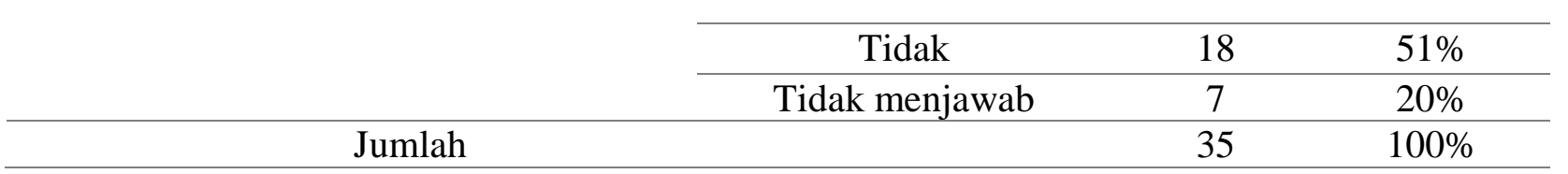

Sumber : Olahan Data Primer, 2017

Berdasarkan hasil penelitian pada tabel 16 di atas, diperoleh keterangan mengenai keterlibatan responden terhadap 3 program PKK yaitu Posyandu, Poslindu dan Jumantik. Responden sebanyak 35 orang, menghasilkan 10 repsonden memiliki prosentase sebesar $29 \%$ menjawab "ya" bahwa responden terlibta dalam 3 kegiatan yang PKK lakukan tersebut, kemudian sebanyak 18 responden dengan prosentase sebesar 51\% menjawab "tidak" dan sisanya sebanyak 7 responden dengan prosentase sebesar 20\% tidak memberikan jawabannya. Bagi responden yang menjawab "tidak" bahwa dari mereka tidak memiliki lansia dalam keluarga sehingga tidak berpartisipasi dalam kegiatan Poslindu atau tidak memiliki balita dalam keluarga sehingga tidak berpartisipasi dalam kegiatan Posyandu.

Tabel 17 Jawaban Responden Tentang Perannya dalam Kegiatan yang dilaksanakan PKK

\begin{tabular}{cccc}
\hline No & Jawaban & Frekuensi & $\begin{array}{c}\text { Prosenta } \\
\text { se }\end{array}$ \\
\hline 1 & Panitia & 1 & $3 \%$ \\
\hline 2 & Pengunjung & 33 & $94 \%$ \\
\hline 3 & Lain-lain & 1 & $3 \%$ \\
\hline & Jumlah & $\mathbf{3 5}$ & $\mathbf{1 0 0 \%}$
\end{tabular}

Sumber : Olahan Data Primer, 2017

Berdasarkan hasil penelitian pada tabel 17 di atas, diperoleh keterangan mengenai peran responden dalam kegiatan yang dilakukan oleh PKK. Responden sebanyak 35 orang, menghasilkan 33 responden memiliki prosentase sebesar 94\% menjawab sebagai pengunjung, kemudian terdapat 1 responden dengan prosentase 
sebesar 3\% menjawab sebagai panitia yaitu panitia tambahan dan sisanya 1 responden memiliki prosentase sebesar 3\% menjawab lain-lain. Satu responden yang menjawab sebagai panitia karena terkadang dalam pelaksanaan kegiatan terdapat kekurangan, sehingga ada pengunjung yang telah dipercaya untuk menjadi panitia.

\subsubsection{Pengetahuan Responden tentang Peran PKK dalam Mensejahterakan Keluarga.}

Tabel 18 Keterangan Tentang Peran PKK dalam Membantu Mensejahterakan

Keluarga Responden

\begin{tabular}{ccccc}
\hline No & Pertanyaan & Jawaban & Frekuensi & Prosentase \\
\hline 1 & $\begin{array}{c}\text { Apakah PKK berperan dalam } \\
\text { membantu mensejahterakan } \\
\text { keluarga Anda? }\end{array}$ & Ya & 33 & $94 \%$ \\
\cline { 2 - 4 } & Jumlah & Tidak & 2 & $6 \%$ \\
\hline & & 35 & $100 \%$ \\
\hline
\end{tabular}

Sumber : Olahan Data Primer, 2017

Berdasarkan hasil penelitian pada tabel 18 di atas, diperoleh keterangan mengenai peran PKK dalam membantu mensejahterakan keluarga responden. Responden sebanyak 35 orang, menghasilkan 33 responden memiliki prosentase sebesar 94\% menjawab "ya" terbantu dengan beberapa kegiatan yang PKK lakukan dan sisanya sebanyak 2 responden dengan prosentase sebesar $6 \%$ menjawab "tidak". Berdasarkan hasil pengamatan dalam kegiatan observasi yang peneliti lakukan, PKK telah mampu membantu mensejahterakan keluarga responden dalam kegiatan Posyandu, Pos Bindu dan Jumantik. Karena dengan kegiatan tersebut kesehatan anggota keluarga responden lebih terbantu sehingga berdampak pada meningkatnya kesejahteraan keluarga.

Tabel 19 Jawaban Responden Tentang Bentuk Bantuan yang diberikan PKK

\begin{tabular}{cccc}
\hline No & Jawaban & Frekuensi & Prosentase \\
\hline 1 & Pelatihan Keterampilan & 34 & $97 \%$ \\
\hline 2 & Dana Bantuan & 0 & $0 \%$ \\
\hline 3 & Lain-lain & 1 & $3 \%$ \\
\hline & Jumlah & $\mathbf{3 5}$ & $\mathbf{1 0 0 \%}$ \\
\hline
\end{tabular}

Sumber : Olahan Data Primer, 2017

Berdasarkan hasil penelitian pada tabel 19 di atas, diperoleh jawaban responden tentang bentuk bantuan yang diberikan PKK. Dari jumlah responden sebanyak 35 orang, hampir seluruhnya menjawab mendapat pelatihan keterampilan yang diberikan oleh PKK untuk meningkatkan kualitas hidup responden yaitu sebanyak 34 responden dengan prosentase sebesar 97\% dan sisanya 1 responden dengan prosentase sebesar 3\% menjawab lain-lain yaitu hanya bantuan raskin yang diterimanya.

Tabel 20 Keterangan Tentang Bantuan yang diberikan Pemerintah Kepada Responden

\begin{tabular}{ccccc}
\hline No & Pertanyaan & Jawaban & Frekuensi & Prosentase \\
\hline 1 & $\begin{array}{c}\text { Apakah Anda mengetahui bantuan yang } \\
\text { diberikan pemerintah kepada keluarga pra } \\
\text { sejahtera ? }\end{array}$ & Ya & 32 & $92 \%$ \\
\cline { 2 - 4 } & Jumlah & Tidak & 3 & $8 \%$ \\
\hline & & & $\mathbf{3 5}$ & $\mathbf{1 0 0 \%}$ \\
\hline
\end{tabular}

Sumber : Olahan Data Primer, 2017

Berdasarkan hasil penelitian pada tabel 20 di atas, dapat diperoleh keterangan mengenai bantuan yang diberikan pemerintah kepada responden. Responden sebanyak 35 orang, menghasilkan 32 responden yang memiliki prosentase sebesar 92\% menjawab "ya" mereka mengetahui bahwa pemerintah telah memberikan bantuan kepada keluarga pra sejahtera termasuk responden dan siasnya sebanyak 3 responden 
dengan prosentase sebesar $8 \%$ menjawab "tidak" karena mereka tidak mengetahui asal bantuan yang mereka terima.

\subsubsection{Tanggapan Responden tentang Kinerja PKK}

Tabel 21 Keterangan Tentang Tanggapan Responden terhadap Kinerja PKK dalam Membantu

Mensejahterakan Keluarga Pra Sejahtera di Wilayah RW 004

\begin{tabular}{clcccc}
\hline No & \multicolumn{2}{c}{ Pertanyaan } & Jawaban & Frekuensi & Prosentase \\
\hline 1 & $\begin{array}{l}\text { Menurut Anda apakah PKK telah } \\
\text { mampu membantu dalam } \\
\text { mensejahterakan keluarga pra } \\
\text { sejahtera? }\end{array}$ & Sudah & 30 & $86 \%$ \\
\cline { 3 - 5 } & & Belum & 5 & $14 \%$
\end{tabular}

\begin{tabular}{rrr}
\hline Jumlah & 35 & $100 \%$ \\
\hline
\end{tabular}

Sumber : Olahan Data Primer, 2017

Berdasarkan hasil penelitian pada tabel 21 di atas, diperoleh keterangan mengenai tanggapan responden terhadap kinerja PKK dalam membantu mensejahterakan keluarga pra sejatera di lingkungan RW 004. Jumlah responden sebanyak 35 orang, menghasilkan 30 responden yang memiliki prosentase sebesar $86 \%$ menjawab PKK sudah mampu meringankan sedikit beban hidup keluarga pra sejahtera contohnya dengan diadakannya kegiatan Posyandu dan Pos Bindu, dan sisanya sebanyak 5 responden yang memiliki prosentase sebesar $14 \%$ menjawab belum karena PKK masih kurang dalam melibatkan langsung masyarakat dalam pelatihan keterampilan yang ada.

Tabel 22 Keterangan Tentang Sosialisasi PKK pada setiap Kegiatan yang akan dilaksanakan

\begin{tabular}{ccccc} 
No & Pertanyaan & Jawaban & Frekuensi & Prosentase \\
\hline 1 & $\begin{array}{c}\text { Apakah PKK telah } \\
\text { mensosialisasikan setiap kegiatan } \\
\text { yang akan dilaksanakan kepada } \\
\text { masyarakat? }\end{array}$ & Ya & 15 & $43 \%$ \\
\cline { 2 - 4 } & & Tidak & 30 & $57 \%$
\end{tabular}

\begin{tabular}{lll}
\hline Jumlah & $\mathbf{3 5}$ & $\mathbf{1 0 0 \%}$ \\
\hline
\end{tabular}

Sumber : Olahan Data Primer, 2017

Berdasarkan hasil penelitian pada tabel 22 di atas, diperoleh keterangan mengenai sosialisasi PKK pada setiap kegiatan yang akan dilaksanakan. Dari 35 responden, menghasilkan 20 responden yang memiliki prosentase sebesar 57\% menjawab "tidak" bahwa PKK masih kurang dalam melakukan sosialisasi pada kegiatan yang akan dilaksanakan dan sisanya sebanyak 15 responden memiliki prosentase sebesar 43\% menjawab "ya" bahwa PKK telah mensosialisasikan kegiatannya.

abel 23 Jawaban Responden Tentang Media yang digunakan PKK dalam Mensosialisasikan Kegiatannya

\begin{tabular}{cccc}
\hline No & Jawaban & Frekuensi & Prosentase \\
\hline 1 & Spanduk & 5 & $14 \%$ \\
\hline 2 & $\begin{array}{c}\text { Surat } \\
\text { edaran }\end{array}$ & 7 & $20 \%$ \\
\hline 3 & Banner & 0 & $0 \%$ \\
\hline 4 & Lain-lain & 23 & $66 \%$ \\
\hline & Jumlah & $\mathbf{3 5}$ & $\mathbf{1 0 0 \%}$ \\
\hline
\end{tabular}

Sumber : Olahan Data Primer, 2017 
Berdasarkan hasil penelitian pada tabel 23 di atas, diperoleh jawaban responden mengenai media yang digunakan PKK dalam mensosialisasikan kegiatan yang akan dilakukan. Jumlah responden sebanyak 35 orang, menghasilkan 23 responden yang memiliki prosentase $66 \%$ menjawab lain-lain yaitu hanya melalui pembicaraan saja dan biasanya responden hanya mendengan dari tetangga saja. Kemudian sebanyak 7 responden memiliki prosentase sebanyak 20\% menajwab sosialisasi dilakukan dengan memberikan surat edaran kepada Ibu RT masing-masing wilayah, dan sisanya sebanyak 5 responden memiliki prosentase sebesar $14 \%$ menjawab sosialisasi dilakukan melalui spanduk yang dipasang.

Tabel 24 Jawaban Tentang Respon dari Responden terhadap Kegiatan yang PKK lakukan

\begin{tabular}{cccc} 
No & Jawaban & $\begin{array}{c}\text { Frekuen } \\
\text { si }\end{array}$ & $\begin{array}{c}\text { Prosenta } \\
\text { se }\end{array}$ \\
\hline 1 & Antusias & 7 & $20 \%$ \\
\hline 2 & Biasa saja & 20 & $57 \%$ \\
\hline 3 & $\begin{array}{c}\text { Tidak } \\
\text { tertarik }\end{array}$ & 8 & $23 \%$ \\
\hline & Jumlah & 35 & $100 \%$ \\
\hline
\end{tabular}

Sumber : Olahan Data Primer, 2017

Berdasarkan hasil penelitian pada tabel 24 di atas, diperoleh jawaban responden mengenai respon mereka terhadap kegiatan yang dilakukan oleh PKK. Dari jumlah responden sebanyak 35 orang, menghasilkan 20 orang responden yang memiliki prosentase sebesar $57 \%$ menjawab biasa saja dalam mengikuti kegiatan yang PKK laksanakan, kemudian sebanyak 7 responden memiliki prosentase sebesar $20 \%$ menjawab antusias, dan sisanya sebanyak 8 responden memiliki prosentase sebesar $23 \%$ menjawab tidak tertarik. Bagi responden yang menjawab "antusias" karena mereka memiliki balita dan lansia dalam keluarga sehingga mereka berpartisipasi dalam kegiatan Posyandu dan Poslindu. Sedangkan bagi responden yang menjawab "tidak tertarik" karena mereka memiliki kesibukan sendiri di luar seperti bekerja di pabrik dan berdagang.

\subsection{Pembahasan}

Berdasarkan data wilayah PKK RW 004, dari jumlah kepala keluarga yang telah disebutkan di atas, terdapat 350 keluarga yang tergolong dalam keluarga pra sejahtera. Data ini menunjukkan penurunan dari data sebelumnya berjumlah 600 keluarga. Namun penurunan ini disebabkan oleh jumlah penduduk yang meninggal dan pindahnya penduduk ke daerah lain.

Tingginya tingkat keluarga pra sejahtera di wilayah RW 004 disebabkan oleh latar belakang pendidikan yang ditempuh. Berdasarkan data dari hasil penelitian yang diperoleh menyatakan bahwa rata-rata terbesar tingkat pendidikan yang telah ditamatkan hanya sampai jenjang SD dan SMP. Rendahnya tingkat pendidikan ini sangat mempengaruhi kesejahteraan masyarakat tersebut. Penghasilan mereka dalam sebulan hanya mencapai kurang dari RP 1.000.000,-. Penghasilan ini responden dapatkan dari pekerjaan sambilan yang dilakukan seperti memotong sisa benang pada baju yang diberikan oleh konveksi di sekitar rumah responden.

Permasalahan keluarga pra sejahtera tersebut menjadi salah satu tujuan dibentuknya PKK agar dapat membantu meningkatkan kesejahteraan keluarga di lingkungan RW 004. Namun faktanya berdasarkan data dari hasil penelitian yang diperoleh dalam penelitian menunjukkan bahwa sebagian besar responden tidak mengetahui tentang PKK yang ada di lingkungannya. Hal ini disebabkan oleh kurang aktifnya PKK dalam memberikan pengumuman atau informasi atau sosialisai tentng kegiatan yang akan dilaksanakan. Selain itu banyak dari responden yang beralasan sibuk bekerja untuk memenuhi kebutuhan hidup sehari-hari. 
Berdasarkan data mengenai pengetahuan responden tentang program kerja PKK ternyata sebagian besar responden tidak mengetahui secara pasti berapa banyak program kerja PKK dan apa saja program kerja tersebut. Hal ini menunjukkan bahwa PKK kurang aktif dalam menjelaskan fungsi, tujuan dan rencana atas keberadaannya untuk masyarakat. Peneliti mencoba bertanya kepada responden tentang 3 program kerja, yaitu Posyandu, Pos Bindu, dan Jumantik. Hasilnya menunjukkan perbedaan respon terhadap tiga program kerja tersebut. Pada program kerja Posyandu seluruh responden antusias mengunjunginya karena responden membutuhkan bantuan untuk mengontrol kesehatan balitanya. Selain itu biaya yang dikeluarkan juga sesuai dengan kemampuan yang responden miliki. Selanjutnya pada program kerja Pos Bindu sebagan besar responden menjawab bahwa mereka mengikuti kegiatan ini karena terdapat anggota keluarga yang tergolong lansia. Dalam kegiatan ini pelayanan yang diberikan berupa pengukuran tinggi badan, pengukuran berat badan, pemberian makanan tambahan, dan pemerikasaan gula darah. Kegiatan Pos Bindu dilaksanakan sebanyak satu kali dalam sebuan. Kemudian pada program kerja Jumantik yang bertugas untuk mengontrol kebersihan lingkungan RW 004 guna mengurangi dampak penyakit yang disebabkan oleh keberadaan jentik-jentik nyamuk.

Dari beberapa program kerja yang dilakukan oleh PKK tersebut menurut sebagian besar responden peran PKK sangat membantu dalam mensejahterakan keluarga pra sejahtera. Selain itu PKK juga pernah melaksanakan pelatihan keterampilan untuk membantu meningkatan kesejahteraan keluarga di lingkungan RW 004. Keikutsertaan masyarakat dalam pelaksaan kegiatan yang dilakukan PKK sangat menentukan dampak dan keberhasilan dari kinerja PKK di lingkungan RW 004. Keterlibatan responden dalam tiga kegiatan yaitu Posyandu, Pos Bindu dan Jumantik telah mencapai 50\% yaitu sebanyak 18 responden.

Selain bantuan yang diberikan PKK yaitu berupa pelatihan keterampilan maupun bantuan dalam kegaitan Posyandu, Pos Bindu, dan Jumantik, responden juga mengetahui bahwa Pemerintah telah memberikan bantuan untuk meningkatkan kesejahteraan dalam keluarga pra sejahtera. Sarana dan prasarana yang ada juga masih kurang memadai. Berdasarkan hasil observasi peneliti, lokasi yang digunakan untuk melakukan kegiatan Posyandu masih kurang luas. Karena lokasi yang digunakan merupakan kantor sekretariat RW 004 atau di halaman rumah warga. Posyandu belum memiliki ruangan sendiri untuk melaksakan kegiatannya. Sehingga menyebabkan penumpukan pasien ketika kegiatan Posyandu berlangsung. Selain itu PKK juga kurang mengemas dengan menarik dalam kegiatannya, sehingga responden biasa saja dalam menanggapi kegiatan yang dilakukan PKK.

Dari hasil penelitian yang telah dilakukan peneliti, PKK adalah agen pemberdayaan untuk masyarakat sekitar terutama lingkunga RW 004. Sebagai yang telah dikemukakan beberapa ahli mengenai pengertian dari pemberdayaan itu sendiri. Pemberdayaan adalah upaya untuk membangun daya itu, dengan memotivasi, mendorong, dan membangkitkan kesadaran terhadap potensi yang dimilikinya serta berupaya mengembangkannya (Kartasasmita, 1996). PKK sebagai agen pemberdayaan telah melakukan tugasnya untuk memberikan kesejahteraan kepada masyarakat dalam bentuk pelayanan melalui Posyandu, Pos Bindu, dan Jumantik.

\section{KESIMPULAN}

Dalam usaha memberdayakan keluarga pra sejahtera di wilayah RW 004, PKK telah menyelenggarakan beberapa program kerja, yaitu :

1. PKK membantu meningkatkan kesejahteraan keluarga pra sejahtera melalui berbagai kegiatan atau program kerja, yaitu Posyandu, Pos Bindu dan Jumantik. Berikut penjelasannya:

2. Setiap kegiatan serta upaya yang dilakukan telah berusaha untuk mesejahterakan keluarga pra sejahtera yang ada di wilayah RW 004. Namun masih terdapat kekurangan yang 
dirasakan oleh masyarakat terutama keluarga pra sejahtera yang ada di wilayah tersebut, antara lain:

a. Kekurangan tersebut terjadi karena kurangnya sosialisasi program kerja yang akan dilaksanakan oleh PKK.

b. Selain itu yang menyebabkan ketidakoptimalan dalam kinerja PKK adalaha kurangnya sarana dan prasarana yang mendukung program kerja PKK. Salah satu contohnya pada kegiatan Posyandu. Ruangan atau tempat yang digunakan dalam kegiatan tersebut tidak dapat menampung banyaknya pasien yang datang.

c. Kader PKK harus mampu mengemas kegiatan yang akan dilaksanakan semenarik mungkin, sehingga mampu menggerakkan masyarakat agar berpartisipasi dengan maksimal dalam kegiatan tersebut.

\section{SARAN}

Berdasarkan dari hasil penelitian yang telah didapat, maka solusi/saran untuk mengatasi masalah yang terjadi di wilayah RW 004 Rawa Buaya Cengkareng Jakarta Barat yang berkaitan dengan PKK dalam pemberdayaan keluarga pra sejahtera, menurut peneliti diperlukan beberapa tindakan untuk penyelesaian masalah tersebut antara lain :

1. Pihak Pemerintah lebih memperhatikan masyarakat kelas menengah ke bawah dengan memperbanyak lapangan pekerjaan dan pelatihan keterampilan, terutama untuk mereka yang memiliki pendidikan yang terbatas. Kegiatan ini dapat disalurkan melalui PKK yang ada di lingkungan masing-masing daerah.

2. Pihak PKK lebih memperhatikan masyarakat yang tergolong dalam keluarga pra sejahtera. Contohnya dalam memberikan pelatihan keterampilan agar mereka dapat meningkatkan kualitas hidupnya dan dapat mandiri dalam menangani masalah ekonomi keluarga. Serta agar dalam masyarakat, stastus sosial mereka dapat lebih dihormati. Selain itu PKK juga harus lebih aktif dalam memberikan informasi kepada masyarakat tentang kegiatan yang akan dilaksanakan, contohnya pembuatan spanduk dan penyebaran surat pemberitahuan agar kegiatan tersebut dapat berjalan sesuai tujuannya dan mengenai sasarannya.

3. Bagi masyarakat lebih aktif dalam mengikuti setiap kegiatan yang dilakukan PKK. Karena dengan mengikuti kegiatan tersebut dapat menambah pengetahuan tentang dunia luar dan dapat memunculkan ide untuk mengembangkan hidup ke arah yang lebih baik.

\section{REFERENSI}

Anwas, O. M. (2013). Pemberdayaan Masyarakat di Era Globalisasi. Bandung. Bandung: Alfabeta.

Arikunto, S. (2008). Prosedur Penelitian Suatu Pendekatan Praktek. Jakarta: Rineka Cipta.

Arisandi, D. (2015). Peran PKK di dalam pemberdayaan perempuan di Desa Muara Bengkal Ilir Kecamatan Muara Bengkal Kabupaten Kutai Timur. 10-11.

Aslichati, L. (2011). Organisasi pemberdayaan dan kesejahteraan keluarga sebagai sarana pemberdayaan perempuan. Jurnal Organisasi Dan Manajemen, 7, 1-7.

Damsar. (2012). Pengantar Sosiologi Politik. Jakarta: Kencana Prenanda Media Grup.

Gall, M., Gall, J., \& Borg, W. (2007). Educational Reasearch: An Introduction (8th ed.). Boston: Pearson.

Lambert, V. A., \& Lambert, C. E. (2012). Pacific Rim International Journal of Nursing Research. Thailand Nursing and Midwifery Council.

Moleong, L. J. (2012). Metode Penelitian Kualitatif. Bandung: PT. Remaja Rosdakarya.

Moleong, L. J. (2016). Metodologi Penelitian Kualitatif Edisi Revisi. Bandung: PT. Remaja Rosdakarya.

Pranarka, A. M. W., \& Moeljarto, V. (1996). Pemberdayaan Konsep, Kebijakan, dan Implementasi. Jakarta: CSIS.

Rantung, J. F., Mandey, J., \& Londa, V. Y. (2014). Peranan Pemberdayaan Kesejahteraan Keluarga (PKK) dalam menggerakkan partisipasi masyarakat desa (Suatu Studi Di Desa 
Ongkau I Kabupaten Minahasa Selatan). Jurnal Administrasi Publik UNSRAT, 4(5), 1246.

Riana, N. R., Sjamsuddin, S., \& Hayat, A. (2014). Pelaksanaan peranan tim penggerak Pemberdayaan dan Kesejahteraan Keluarga (PKK) dalam memberdayakan perempuan. Jurnal Administrasi Publik (JAP), 2(5), 851-856.

Sudijono, A. (2010). Pengantar Statistik Pendidikan. Jakarta: Raja Grafindo Persada.

Sugiyono. (2010). Memahami Penelitian Kualitatif. Bandung: Alfabeta.

Sugiyono. (2012). Metode Penelitian Pendidikan. Bandung: Alfabeta.

Sunarti, E. (2011). Kependudukan dan Keluarga Sejahtera. Jurnal IPB.

Sungarimbun, M., \& Efendi, S. (2008). Metode Penelitian Survey. Jakarta: LP3ES. 